\title{
8 Support for older adults during COVID-19
}

\author{
How did local authorities in the \\ Pomeranian region respond to \\ the challenge?
}

Anita Richert-Kaźmierska

The COVID-19 pandemic, apart from health threats, has shown the problem of older adults' social isolation and loneliness in aging societies that has been progressing for several decades. Older adults' singularisation, loosening family relations, diminishing families' caring potential, caused that during the lockdown, many older adults without the neighbours' or NGOs' support or the activities undertaken by local authorities - would be left without meeting their basic life and social needs. Authors draw their attention to the different aspects of population aging process and its socio-economic consequences. Nevertheless, the subject of older adults' loneliness and the growing role of institutions (coordinated by local government authorities) in providing them different care services still seems insufficiently researched in the Polish-language literature. In Polish society, citizens prefer that the informal care needs of older adults are assiduously met by family members. However, the months of the COVID-19 pandemic lockdown have clearly shown that this traditional model of informal care is not always possible in practice, and that family members are increasingly turning to regional local authorities to assist them in the care requirements of older and frail relatives . Many family members are not always ready to provide care for older relatives at home due to a lack of appropriate knowledge and assistive aids.

\section{Introduction}

The older adults' support system in Poland is based on the hierarchical compensation care model, where responsibility regarding older adults' care and meeting older adults' needs is treated as a 'family matter': older adults' spouses and/or children are expected to take the full responsibility for providing the support, including long-term care. In small-town and rural societies, asking an institution for help to removing an older adult to a specialised 
centre causes family's stigmatization and accusation of soullessness or lack of gratitude.

The older adults' singularization (living alone) requires a review of this approach and more frequent and intensive inclusion of local self-help networks (neighbours and peer groups), non-governmental organisation and local authorities in the older adults' support system. The need for cooperation of various entities in providing support for older adults (a complementary care model) was experienced during the social isolation caused by the COVID-19. In many cases the assistance received by older adults from their family members proved insufficient.

The purpose of this study is to identify and classify the forms of support that local authorities in the Pomeranian Region offered to older adults during the first stage of lockdown caused by the COVID-19 pandemic. Apart from that, based on such experiences, the author intends to develop the concept of effective ways of supporting older adults during crisis situations in future.

\section{Local authorities in older adults' support system in Poland}

Supporting older adults is about providing them with a variety of resources (emotional, informational, material, financial) when they are experiencing difficulties and are unable to cope with them on their own. The insufficient availability of such support results in the needs of the older adults not being met or not sufficiently met (Błędowski et al. 2017). Ultimately, it leads to the deterioration of their social and living conditions, their health, or even to loss of life. The organisation of the support system for older people depends on many factors and differs from country to country. The differences concern, among others: the forms of support and their availability (Błędowski et al. 2017), the degree of institutionalisation of the system, i.e., the responsibility (formal and customary) of family members and institutions for providing support and care to older adults (Gibson et al. 2003), the rules of functioning of support providers and the way of financing their activities (Jurek 2012; Riedel \& Kraus 2011), as well as the supervisory and control bodies of such a system and the scope of their powers (Genet et al. 2012).

The system of support and care for the older adults in Poland is closest to the hierarchical-compensatory model. ${ }^{1}$ The family is seen as the most desired, natural environment of emotional functioning and life activity of older adults, guaranteeing the satisfaction of their needs. ${ }^{2}$ The responsibility for providing support and care for the older adults rests, respectively, on their children, spouses, siblings, grandchildren and other relatives (CBOS 2019). The support and institutional care ${ }^{3}$ are treated as complementary to family care and the permanent transfer of a senior citizen to a long-term care facility is perceived to be only as the last resort (Cantor 1989). As Janowicz (2014: 162) observes, "in smaller environments it happens that giving a loved one up to a specialist centre results in stigmatization of their family and a 
suspicion of heartlessness or lack of gratitude on the part of their children and grandchildren".

Due to a range of social changes taking place due to women becoming engaged in the labour market and smaller family household, but especially the singularisation of old age (Heinze \& Naegele 2009) and the decreasing caring capacity of families (Błachnio 2016), the demand for active participation of non-governmental organisations and public institutions in the system of support for older adults is systematically increasing. Local government, as the "closest to the citizens", has a special responsibility in this respect. It is a provider of statutorily guaranteed social services to older adults, but also an initiator and a coordinator of activities undertaken locally by other entities. According to the provisions of the Polish Social Welfare Act (Ustawa $\mathrm{z}$ dnia 12 marca 2004 r. o pomocy społecznej (Dz.U.2004, 64: 593), the district is obliged to provide assistance to older adults on the same principles as other groups of beneficiaries "in need of support" (people who, due to age, illness or disability, require partial care and assistance in meeting their vital needs). However, more and more local governments ${ }^{4}$ decide to improve upon the catalogue of compulsory activities related to older adult support and implement local old age policies. They include, among others, activities in the field of health prevention, social activation of older adults, increasing the availability of care services for older adults in their place of residence, or supporting family carers (Table 8.1).

\section{Senior citizens' needs during the COVID-19 pandemic}

Due to their heterogeneity (age, health condition, level of independence, family situation, material situation), older people declare different needs which they are able to satisfy on their own or in relation to which they require support from family members, third parties and/or institutions. Both groups of needs can include material, spiritual, emotional and cultural needs, as well as needs related to daily activities or physiological and health needs (Błędowski 2002). Tibbitis (1967) arranges them into ten groups, which in turn can be arranged according to the hierarchy proposed by Maslow (2009). According to Maslow, humans strive to satisfy their needs sequentially, starting from physiological (life, organic) ones and ending with those related to the desire to realise one's potential and personal development - cf. Figure 8.1.

The needs of older people - as a rule - are not significantly different from those felt at earlier stages of life. However, their hierarchy and intensity may vary. Due to the deteriorating health condition, lower activity and physical fitness, as well as changes in social relations, the need for closeness, acceptance (being needed), support in everyday activities and a sense of security becomes most important in old age (Nosek 2016; Trafiałek 2003).

The COVID-19 pandemic had various social and economic consequences (Peterson \& Thankom 2020). Its impact on the situation of older adults is 


\section{Anita Richert-Kaźmierska}

Table 8.1 The tasks of district self-government in the support system for older adults in Poland

\begin{tabular}{|c|c|c|}
\hline \multirow[t]{7}{*}{ Mandatory $^{\mathrm{a}}$} & $\begin{array}{l}\text { Distribution of } \\
\text { cash benefits }\end{array}$ & $\begin{array}{l}\text { Granting and payment of periodic and special purpose } \\
\text { allowances, } \\
\text { Paying a pension insurance contribution for individuals } \\
\text { resigning from employment because of the need to take } \\
\text { direct personal care of a long-term or seriously ill family } \\
\text { member or their mother, father or siblings who do not live } \\
\text { together, } \\
\text { Paying for the stay of a district resident in a residential care } \\
\text { home }\end{array}$ \\
\hline & Provision of & Social work, \\
\hline & benefits in & In-kind help, \\
\hline & kind (social & Specialist advice and crisis intervention, \\
\hline & services) & $\begin{array}{l}\text { Providing shelter, food and necessary clothes, } \\
\text { Care services in the place of residence, in support centres } \\
\text { and in family care homes, }\end{array}$ \\
\hline & & $\begin{array}{l}\text { Specialist care services in the place of residence and in } \\
\text { support, residence and service centres in the residential } \\
\text { care home, }\end{array}$ \\
\hline & & $\begin{array}{l}\text { Assistance in obtaining appropriate housing conditions, } \\
\text { Training and family counselling }\end{array}$ \\
\hline \multirow[t]{16}{*}{ Optional } & $\begin{array}{l}\text { preventive } \\
\text { healthcare }\end{array}$ & $\begin{array}{l}\text { implementation of preventive programmes (e.g. vaccination } \\
\text { against influenza and pneumococcus, screening) } \\
\text { financing of rehabilitation procedures, including home } \\
\text { rehabilitation }\end{array}$ \\
\hline & $\begin{array}{l}\text { Promoting social } \\
\text { inclusion and }\end{array}$ & $\begin{array}{l}\text { Implementation of the principles of universal design in } \\
\text { investment projects }\end{array}$ \\
\hline & $\begin{array}{l}\text { combating } \\
\text { discrimination }\end{array}$ & $\begin{array}{l}\text { Adapting the existing district infrastructure to the needs of } \\
\text { older people with reduced mobility and the disabled }\end{array}$ \\
\hline & & $\begin{array}{l}\text { Actions aimed at strengthening intergenerational } \\
\text { cooperation }\end{array}$ \\
\hline & & $\begin{array}{l}\text { Developing neighbourhood and intergenerational } \\
\text { volunteering }\end{array}$ \\
\hline & & $\begin{array}{l}\text { Social campaigns for positive ageing and social inclusion of } \\
\text { senior citizens }\end{array}$ \\
\hline & & $\begin{array}{l}\text { Implementing institutionalised advocacy for the interests of } \\
\text { older people }\end{array}$ \\
\hline & Social activation & $\begin{array}{l}\text { Investing in infrastructure dedicated to the older adults } \\
\text { (meeting places for senior citizens, open gyms) }\end{array}$ \\
\hline & & $\begin{array}{l}\text { Organizing leisure time (financing the activities of senior } \\
\text { citizen clubs and associations) }\end{array}$ \\
\hline & & $\begin{array}{l}\text { Organization of educational, recreational and sports } \\
\text { activities }\end{array}$ \\
\hline & & Cultural offer dedicated to older adults \\
\hline & & Actions for intergenerational integration \\
\hline & & $\begin{array}{l}\text { Support for mobility by providing individual door-to-door } \\
\text { transport services }\end{array}$ \\
\hline & Safety and & Psychological and legal assistance \\
\hline & security & $\begin{array}{l}\text { Home telecare service, with the support of a telecare } \\
\text { assistant }\end{array}$ \\
\hline & & Prevention of various forms of violence against older people \\
\hline
\end{tabular}

${ }^{\mathrm{a}}$ The forms of support for individuals who, due to age, illness or disability, require partial care and assistance in meeting their necessary life needs, that are obligatory for local government units, are defined in the Polish Social Welfare Act [28]. 


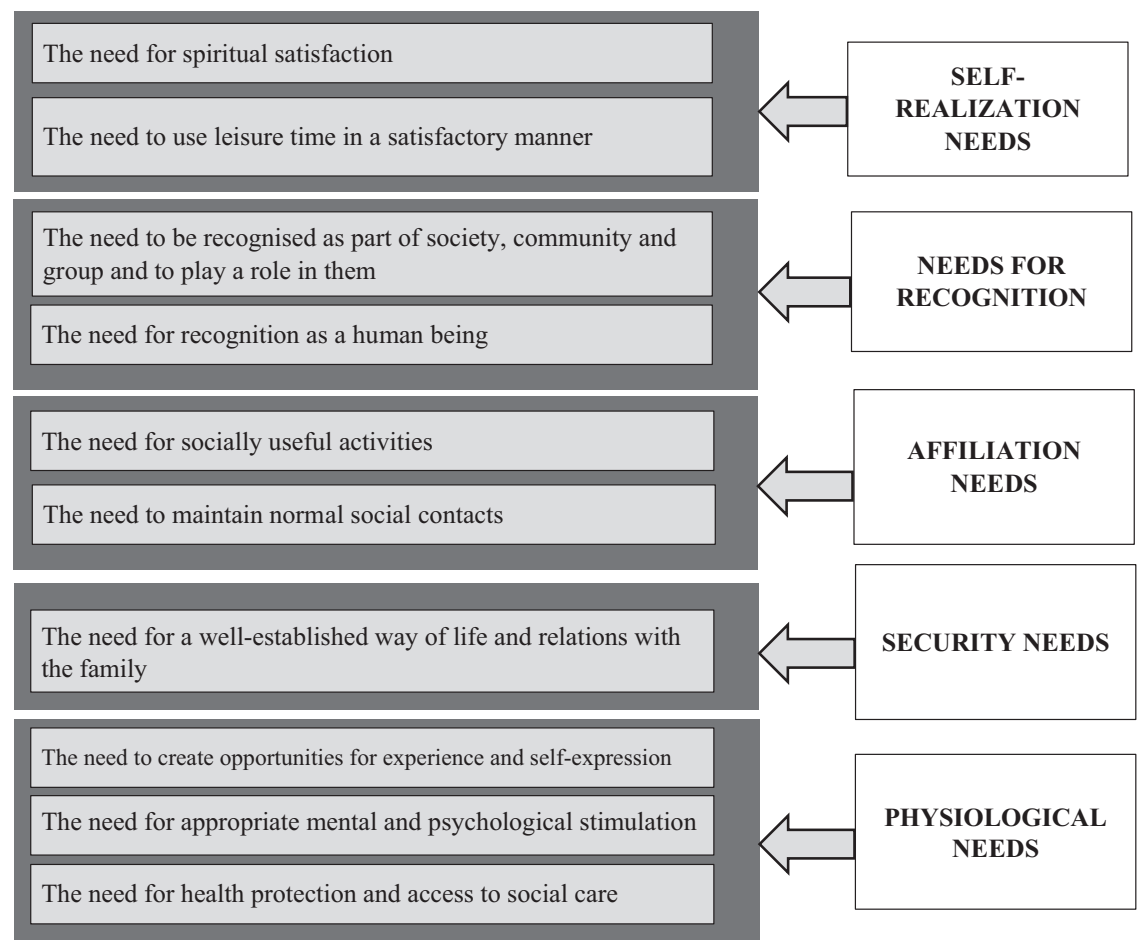

Figure 8.1 The needs of older people in the classification of C. Tibbits hierarchy of A. Maslow.

intensified by the fact that older age is the main risk factor of death in case of SARS-CoV-2 infection (Petretto \& Pili 2020). In the spring of 2020, almost overnight, the older adults became socially isolated as belonging to the highest risk group. For the sake of older people's health, personal contacts between family members were restricted, the activities of institutions organizing leisure time for older adults were suspended, recommendations not to leave home and restrictions on free movement outside the place of residence were introduced, and the availability of various types of social services in a direct personal form (e.g. visits to a doctor, rehabilitation services or participation in religious services) was limited or suspended. The time of the COVID-19 pandemic highlighted - more than ever before - the problems and unmet needs of older people: above all, social isolation and loneliness, age discrimination, insufficient access to health prevention, medical care and care services, as well as lack of or insufficient access to information (Przybył et al. 2020; United Nations 2020).

For many older adults - despite lack of actual infection with the virus COVID-19 has become the cause of a serious life crisis. It disrupted their earlier, "normal" functioning, caused or deepened the feeling of loneliness, increased the feeling of distrust towards strangers, as well as aroused fear 
for the health and life of themselves and their loved ones (Morrow-Howell 2020; Prawa człowieka osób starszych podczas pandemii 2020; Zangh \& Song 2020). As with any crisis situation, the reactions of older adults to a new situation are different (Parker \& Endler 1992): concentration on task, concentration on emotions or concentration on avoidance - cf. Table 8.2.

\section{Activities for the benefit of older adults undertaken by local governments in the Pomorskie province during the COVID-19 pandemic}

The COVID-19 pandemic forced the whole system of state administration to perform new tasks. Both the central government and the local governments faced the challenge of meeting the security needs of citizens by reducing the level of the epidemic itself on the one hand and supporting those affected on the other.

The local government is the organisational structure of the local community, located closest to the citizens in the hierarchy of power in a state. Therefore, the needs for support in crisis situations are first of all reported by citizens to the district authorities. As regards the fight against the COVID-19 epidemic, the activities of local self-government authorities are largely determined by the procedures generated at the government level and should be strictly harmonised with the activities of the government administration and its entities, as well of the local governments at the county and province level. They represent a huge challenge for local authorities - primarily due to the multitude and variety of tasks that fall into the scope of statutory responsibility of districts (own tasks and those commissioned by the government administration), the deficit of local government employees, or the difficult financial situation that had existed in many of them already before the outbreak of the epidemic (Berenda 2020; GUS 2019; Local governments: we help, but we also need support 2020).

According to the Polish Act on special solutions related to preventing, counteracting and combating COVID-19, other infectious diseases and crisis situations caused by them (Act on special solutions related to the prevention, counteraction and combating COVID-19, other infectious diseases and crisis situations caused by them (Dz.U. 2020, 374), article, 10, paragraph, 1), the Prime Minister, at the request of the Minister of Health, may impose an obligation on a local government unit to perform a specific task in connection with counteracting the COVID-19 epidemic. Moreover, in connection with the counteraction of COVID-19, by means of an administrative decision, the territorially competent provincial governor may also issue instructions applicable to all local and regional authorities (Act on special solutions related to the prevention, counteraction and combating COVID-19, other infectious diseases and crisis situations caused by them (Dz.U. 2020, 374), art. 11, par. 1).

In the classification proposed by Klimek, aid activities undertaken by local government units in the fight against SARS-CoV-2 were divided into 
Table 8.2 Senior citizens' attitudes and behaviour towards the COVID19 crisis

\begin{tabular}{|c|c|c|}
\hline $\begin{array}{l}\text { Attitudes } \\
\text { towards a crisis } \\
\text { situation }\end{array}$ & Possible behaviours & $\begin{array}{l}\text { Needs affecting the } \\
\text { specific behaviours of } \\
\text { older adults }\end{array}$ \\
\hline $\begin{array}{l}\text { Focus on the } \\
\text { task }\end{array}$ & $\begin{array}{l}\text { Striving to maintain a positive } \\
\text { attitude towards the surrounding } \\
\text { reality } \\
\text { Continuing previous (routine, } \\
\text { customary) activities outside } \\
\text { home (e.g. going shopping, } \\
\text { participating in senior citizens' } \\
\text { clubs) while observing safety } \\
\text { recommendations } \\
\text { With restrictions on going } \\
\text { outside the place of residence, } \\
\text { maintaining remote (telephone, } \\
\text { Internet) contact within the } \\
\text { network of family and social } \\
\text { relations } \\
\text { Engaging in various tasks and } \\
\text { initiatives (e.g. sewing masks) and } \\
\text { participating in online activities } \\
\text { dedicated to older adults }\end{array}$ & $\begin{array}{l}\text { Striving for "normality" } \\
\text { and functioning at a } \\
\text { fixed rhythm of the } \\
\text { day } \\
\text { The need for security } \\
\text { The need for affiliation } \\
\text { The need to be useful }\end{array}$ \\
\hline $\begin{array}{l}\text { - Focus on } \\
\text { emotions }\end{array}$ & $\begin{array}{l}\text { Focusing on collecting and } \\
\text { analysing (the main topic of the } \\
\text { discussions) information on the } \\
\text { risks associated with COVID-19 } \\
\text { and the actions taken by the } \\
\text { various institutions in this area } \\
\text { Wishful thinking, not taking any } \\
\text { action (remaining in a specific } \\
\text { state of suspension pending a } \\
\text { return to "normality") } \\
\text { Catastrophic thinking often leading } \\
\text { to mental problems (psychoses, } \\
\text { anxiety, depression, aggression) }\end{array}$ & $\begin{array}{l}\text { A disturbed sense of } \\
\text { stability and security } \\
\text { Emotional lability } \\
\text { Feeling lonely in a crisis } \\
\text { situation } \\
\text { The need to relieve } \\
\text { emotions and fear, for } \\
\text { example by talking to } \\
\text { another person } \\
\text { Insufficient access to } \\
\text { reliable information }\end{array}$ \\
\hline $\begin{array}{l}\text { - Focus on } \\
\text { evasion }\end{array}$ & $\begin{array}{l}\text { Rejection of thoughts about the } \\
\text { problem } \\
\text { Demonstrating the denial of the } \\
\text { existence of a pandemic and its } \\
\text { associated dangers (affirmation } \\
\text { of a conspiracy theory, ignoring } \\
\text { safety rules) } \\
\text { Indifference to the problem and } \\
\text { dissociating oneself from the } \\
\text { information about the pandemic } \\
\text { coming from the environment } \\
\text { An "escapist" attitude, expressed } \\
\text { as falling into addictions or } \\
\text { above-average engagement in } \\
\text { substitution activities }\end{array}$ & $\begin{array}{l}\text { A sense of } \\
\text { powerlessness and } \\
\text { helplessness } \\
\text { Low self-esteem } \\
\text { Fatalism } \\
\text { Loneliness } \\
\text { Lack or inadequacy } \\
\text { of mental support, } \\
\text { related to missing } \\
\text { family, peer and } \\
\text { social relations }\end{array}$ \\
\hline
\end{tabular}


Table 8.3 Areas of local government support for senior citizens during the COVID-19 pandemic

\begin{tabular}{ll}
\hline & Recipients (beneficiaries) \\
\hline $\begin{array}{l}\text { Area 3: Support for social } \\
\text { assistance units providing } \\
\text { services to older adults }\end{array}$ & $\begin{array}{l}\text { Residential care homes } \\
\text { Day care and 24-hour care facilities for seniors } \\
\text { Area 4: Support for the } \\
\text { senior residents of the district }\end{array}$ \\
$\begin{array}{c}\text { Seniors residing in their flats/houses - residents } \\
\text { of the district } \\
\text { Seniors residing in residential care homes and } \\
\text { other day and day-and-night care institutions }\end{array}$ \\
\hline
\end{tabular}

four areas: support for health care, support for the economy, support for social assistance units and support for residents (Klimek 2020). Activities undertaken by local (district) governments for the benefit of older adults belong mainly to the third and the fourth area - cf. Table 8.3.

In order to identify what kind of actions local governments actually took during the pandemic for the benefit of senior residents, the author conducted a survey among the districts of the Pomorskie province. Out of 123 districts in the Pomorskie province, 10 were selected for the study: 2 urban-rural and 8 rural ones (cf. Table 8.4). Each of them - in accordance with the Act on Access to Public Information (Ustawa z dnia 6 września 2001r. o dostępie do informacji publicznej (Dz. U.2014, 782, 1662; Dz.U.2015, 1240) - was asked (by sending an e-mail to the address of the district office's secretariat) for public information in two areas:

(a) the forms and methods of support for the senior residents of the district which were implemented in the period from 1 March to 31 July 2020 in response to threats and limitations caused by the COVID-19 pandemic,

(b) the institutions and organisations (including initiatives of individuals) which joined in providing support to seniors in the district during the pandemic period.

The scope of the questions met the criteria justifying the right of access to public information, as defined in article 6, paragraph 1 of the Act on Access to Public Information. As a result, all the districts to which the inquiry was addressed sent their replies within 21 days from the date of sending the inquiry. The answers, depending on the district, were sent (as confirmed by the signature on the document or in the return e-mail) by the district leaders, the secretaries of the districts, the managers and employees of the district social welfare centres or the head of the village council responsible for senior citizen matters.

The aim of the study was to diagnose the activities actually undertaken by the pomorskie province districts for the benefit of older adults during the period of social isolation caused by the COVID-19 pandemic and to identify 
Table 8.4 Pomorskie province districts which were inquired about the support for seniors during the COVID-19 pandemic

\begin{tabular}{lllll}
\hline District & County & Type of district & $\begin{array}{l}\text { Total } \\
\text { population }\end{array}$ & $\begin{array}{l}\text { Share of } \\
\text { individuals aged } \\
\text { 60 and more (\%) }\end{array}$ \\
\cline { 4 - 5 } & & & - Data for 2019 \\
\hline Bytów & bytowski & Urban-rural & 25,420 & 21.7 \\
Koczała & człuchowski & Rural & 3,356 & 26.4 \\
Kolbudy & gdański & Rural & 17,839 & 18.1 \\
Konarzyny & chojnicki & Rural & 2,311 & 17.5 \\
Kosakowo & pucki & Rural & 15,589 & 15.7 \\
Lipnica & bytowski & Rural & 5,216 & 20.8 \\
Osiek & starogardzki & Rural & 2,376 & 27.2 \\
Smętowo & starogardzki & rural & 5,185 & 21.9 \\
$\quad$ Graniczne & & & & \\
Wicko & lęborski & rural & 6,019 & 20.4 \\
Żukowo & kartuski & Urban-rural & 40,837 & 15.2 \\
\hline
\end{tabular}

organisations, institutions and people with whom they cooperated in this area. The study was of a qualitative nature and therefore the results obtained do not allow for analyses based on statistical methods. On the other hand, the identified solutions may constitute a base of good practices, in the perspective of the so-called second wave of the pandemic and the necessity of the districts' renewed crisis involvement in additional support dedicated to older adults.

Only three of the surveyed districts declared the implementation of tasks in area 3: support for social assistance units dealing with older adults. First of all, these were the districts of Koczała and Kolbudy, in which there are senior citizens' clubs co-financed by the governmental Senior+ programme. Taking into account the needs of these units, both districts:

purchased personal protective equipment (masks, disposable gloves), as well as disinfectants and equipment necessary for their application, purchased additional equipment (plastic safety barriers) and appliances (thermometers) necessary to ensure the safe stay of older adults and staff working conditions,

developed and implemented special security procedures.

In the Koczała district, one of the rooms in the Senior+ Club was additionally arranged to isolate individuals who would show symptoms of disease during classes. The Wicko district, in turn, carried out professional disinfection of all public places where classes dedicated to older adults are held.

Activities in area 4, that is support for older residents of the district, were implemented by all districts in the period from 1 March to 31 July 2020 (Figure 8.2). All districts declared the uninterrupted operation of their 


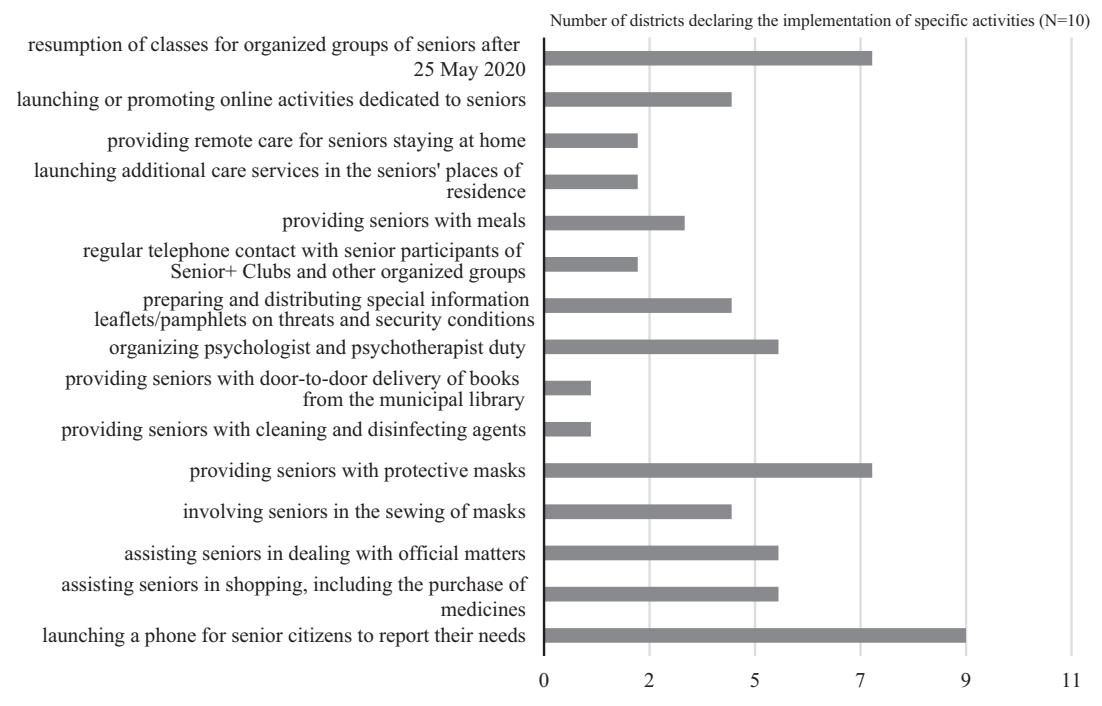

Figure 8.2 Activities supporting older adults during the pandemic, undertaken by local governments participating in the survey of districts.

social welfare centres and the provision of social services to individuals requiring support (including older adults), provided for in the Social Welfare Act Ustawa z dnia 12 marca 2004 r. o pomocy społecznej (Dz.U.2004, 64:593). Almost all of the surveyed districts have launched a special telephone number which can be used by older adults in need of help, e.g., in shopping, buying medicines, arranging an over-the-phone consultation with a physician, dealing with official matters, etc. In the Koczała and Lipnica districts, due to the introduction of such a solution, the working hours of social workers were extended (the phone number dedicated to older adults was operated by employees of the district social welfare centres). In almost all districts protective masks were provided to older adults.

The activities undertaken in the period from 1 March to 31 July 2020 by the local governments involved in the study, in relation to older adults, were mainly in line with three groups of needs, i.e., physiological needs, safety needs and affiliation needs - see Figure 8.3.

The local governments have undertaken activities to support older adults on the basis of the results of a systematic analysis of the needs of the older adults carried out by the district social welfare centre or the district leaders' proxy for senior citizens (Osiek, Kolbudy), ongoing monitoring of the needs of senior citizens carried out by the village leaders (Konarzyny), a questionnaire sent out to senior citizens (Kosakowo), or in response to specific signals reported by the residents of the district to the district office or the district social welfare centre (Lipnica). 


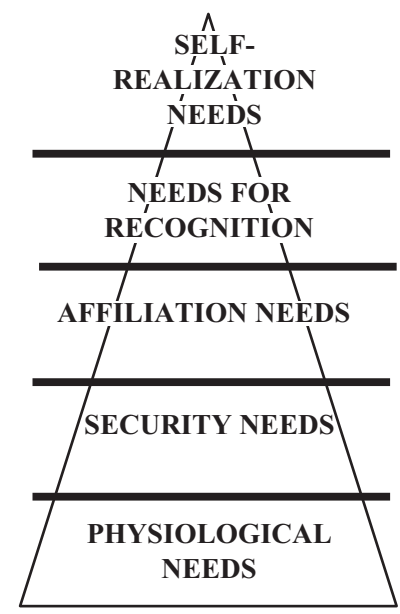

telephone contact with seniors, supplying books from libraries, involving seniors in sewing masks, organizing remote and stationary classes during the pandemic after 25 May 2020

telecare, provision of masks for seniors, provision of disinfectants, distribution of leaflets with reliable information on risks and prevention, on-call duty of and consultations with a psychologist

provision of meals for seniors, assistance with shopping and purchase of medicines, care services at the place of residence of the seniors, financial assistance from the district social welfare centre

Figure 8.3 Activities supporting older adults during the pandemic, undertaken by local governments participating in the survey of districts, in the context of Maslow's hierarchy of needs.

Within activities supporting older adults during a pandemic, local governments performed various functions: they were initiators, coordinators, financing entities or executors. And so, the Żukowo district was i.a. the initiator of the informational and social campaign "Take care of the senior", the aim of which was to encourage the residents to pay more attention to the needs of the older adults in their families, as well as older friends and neighbours, and to offer them help. Konarzyny district (as the District Social Welfare Centre in Konarzyny) coordinated activities supporting older adults carried out in its territory by the Polish Red Cross (acquiring and handing over food parcels), the Association for the Development of the Municipality and District of Debrzno (acquiring and handing over cleaning products to older adults), or the Association for the Support of Children and Youth "Klub Mam" (handing over masks sewn by members of the association to older adults). Kolbudy district funded and purchased protective masks, and the village leaders supplied to the older adults living in their villages. Kolbudy and Koczała funded and purchased the necessary equipment for the Senior+ Clubs operating on their premises in order to ensure the safety of club participants and staff.

The partners of supporting activities during the COVID19 pandemic were e.g. district organisational units, local non-governmental organisations and entrepreneurs, district volunteer fire brigades, as well as village leaders and volunteers (Table 8.5). 
Table 8.5 Partners in the activities of local governments supporting older adults during the pandemic - examples

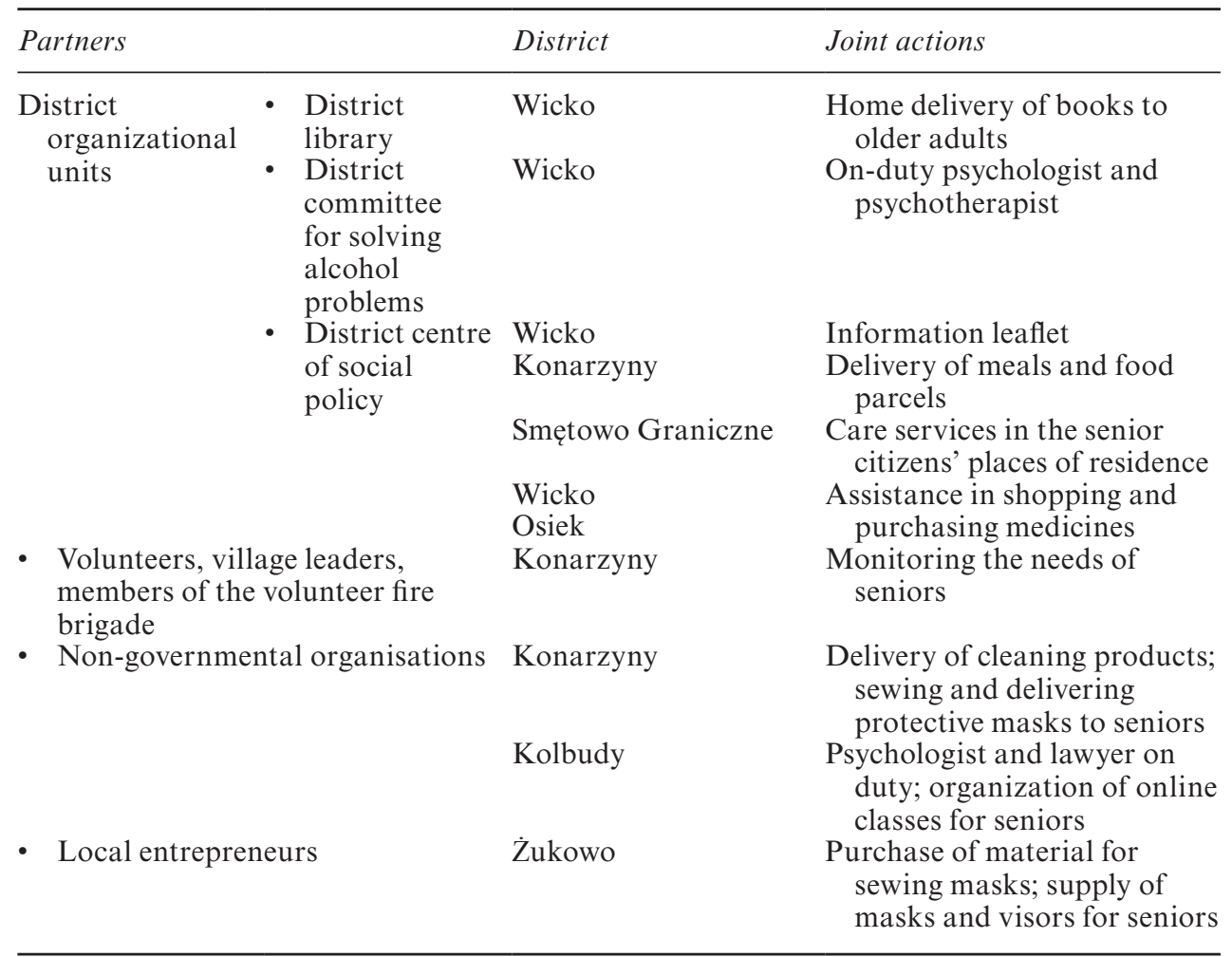

Source: Author's own work.

\section{For further discussion...}

The COVID-19 pandemic represents a double threat for older adults. First of all, a health risk: the infection is most severe (due to reduced immunity and the occurrence of concomitant diseases) among people aged 60 and over, which is reflected in the death rate due to COVID-19 being highest in this group. The second threat is social isolation. Fearful for their health and life, during the pandemic older people were excluded from society more than ever. They were left in their homes, without contact with loved ones and peers. Since a large proportion of them do not have sufficient digital competences, the prosthesis of human relations provided by the Internet is not available to them either. As a result of research carried out in the early stages of the pandemic and national lockdown, it turned out that many older adults are not able to satisfy even their basic - physiological - needs (there is no one to buy them staples or drugs). They also suffered significant deficits in terms of the need for security and affiliation.

The changes that have been taking place for several decades make families and their support for older adults insufficient. Public authorities mainly local governments - must be involved in the process of meeting the 
needs of older people. The crisis situation caused by the COVID-19 pandemic has shown that not all districts are equally prepared for this. Most of them do not have a diagnosis of the needs of older adults (including in the event of an emergency). Their countermeasures were most often ad hoc responses to individually reported signals of necessary assistance. In the answer received from the district of Lipnica, it was explicitly stated that "there was no need to take emergency action as no cases of seniors' requiring support were reported to us in connection with the quarantine or other situations requiring our intervention under the COVID-19 restrictions". The main responsibility for possible satisfaction of the needs of older residents during the pandemic was transferred to the district social welfare centres. It was done despite the fact that few older adults are beneficiaries of this institution on a daily basis and district social welfare centres have no information about such persons.

On an ongoing basis and in a rather chaotic way, partners for cooperation in the field of supporting senior residents of districts were sought. The local leaders in rural districts, i.e., the village leaders, turned out to be most reliable. Among the survey participants, only the Żukowo district indicated good cooperation with a local entrepreneur.

The experience gained during the first wave of the pandemic (from 1 March to 31 July 2020) should form the basis for developing action plans for local governments in the event of a second (autumn) wave of cases or other similar events in the future. The list of important and urgent actions to be taken by the local authorities participating in the survey, but probably also the remaining ones, should also include, among others:

- preparation of a diagnosis of the situation of the older residents, i.e., primarily recognizing the phenomenon of the singularization of old age and assessing the level of caring capacity of their families,

- support in the development and professionalization of volunteering, including neighbourhood volunteering and older adult volunteering,

- developing a system for collecting information on the needs of older adults in crisis situations and a system for providing them with information on the offer of assistance activities available in the district,

- building permanent inter-sectoral partnerships (local government unit/ non-governmental organisation/entrepreneurs), mutually complementary as regards the benefit of the local community, including the older adults (development of local social capital), is concerned.

\section{Notes}

$1 \mathrm{Z}$. Szweda-Lewandowska [24] identifies five types of models for the organisation of senior care systems: the hierarchical compensatory model, the substitutional model, the specificity model, the supplementation model and the complementarity model.

2 According to EuroCarers statistics, $93.5 \%$ of dependent persons in Poland receive care from family carers [30]. 
3 The institutional care for older adults in Poland is implemented in two areas: health care and social assistance. The patients who do not require hospital treatment but nevertheless have significant deficits in health and self-care benefit from long-term care in the health care system, i.e. from care, nursing, rehabilitation, palliative and hospice services, in a specialised facility (inpatient care) or at their home (community care). Care services provided within the framework of social assistance are, in turn, available to individuals who, due to age, illness or disability, require the assistance of other people and are deprived of it [28]. The care services in this case mainly include "assistance in meeting daily life needs, hygiene care, doctor-advised care and, where possible, ensuring the possibility of contact with the environment".

4 The results of the research carried out by the author in the years 2012-2018 indicated that local governments in Poland did not diagnose the demographic changes taking place in their territory, did not recognise the needs of the growing subpopulation of seniors and did not take action to allow for seniors and the ageing of local communities, or such action was insufficient. In recent years, upon participation in multiple research projects and work on local strategies for solving social problems, the author sees a positive change in the attitude of local authorities to the issue of population ageing and actions towards older people.

\section{References}

Act of March 12, 2004 on social assistance (Dz.U.2004, 64:593).

Act on special solutions related to the prevention, counteraction and combating COVID-19, other infectious diseases and crisis situations caused by them (Dz.U. 2020, 374).

Berenda K., Alert gospodarczy: Rola jednostek samorzadu w powstrzymywaniu zapaści gospodarczej, (available 6th of May 2020), https://www.rmf24.pl/raporty/ raport-koronawirus-z-chin/komentarze-ekspertow/news-alert-gospodarczyrola-jednostek-samorzadu-w-powstrzymywaniu, nId, 4424551

Błachnio A., Starość w rodzinie. Opieka nad seniorem wyzwaniem dla dorosłego dziecka czy państwa?, Wychowanie w Rodzinie t. XIII (1)/2016, p. 441-453.

Błędowski P., Lokalna polityka społeczna wobec ludzi starych, Oficyna Wydawnicza Szkoły Głównej Handlowej, Warszawa 2002.

Błędowski P., Szatur-Jaworska B., Szweda-Lewandowska Z., Zrałek M., Model wsparcia społecznego osób starszych $w$ środowisku zamieszkania, In: B. Szatur-Jaworska, P. Błędowski (eds.), System wsparcia osób starszych w środowisku zamieszkania - przegląd sytuacji, propozycja modelu. Synteza. Raport z prac Komisji Ekspertów ds. Osób Starszych przy Rzeczniku Praw Obywatelskich, Biuro Rzecznika Praw Obywatelskich, Warszawa 2017, pp. 13-46.

Cantor M., Social care: Family and community support systems, The Annals of the American Academy of Political and Social Science 503(1)/1989, p. 99-112.

CBOS, Jakiej pomocy potrzebuja osoby starsze i kto im jej udziela?, Komunikat z badań nr 116, CBOS, Warszawa 2019.

Genet N., Boerma W., Kroneman M., Hutchinson A., Saltman R. (eds.), Home care across Europe. Current structure and future challenges, WHO, Copenhagen 2012.

Gibson M.J., Gregory S.R., Pandya S.M., Long-term care in developed nations: A brief overview, Working papers 2003-13, AARP Public Policy Institute, Washington 2003, p. 5-7.

GUS, Gospodarka finansowa jednostek samorzadu terytorialnego 2018, Główny Urząd Statystyczny, Warszawa 2019.

Heinze R., Naegele G., Silver economy in Germany - more than only the economic factor: Old age, Gerobilim 02/2009, p. 37-52. 
Janowicz A., Rola opiekunów nieformalnych w opiece u kresu życia. Przyczynek do badań w ramach projektu European Palliative Care Academy (EUPCA), Pielęgniarstwo i Zdrowie Publiczne, 4(2)/2014, p. 161-167.

Jurek Ł., Ekonomia starzejącego się społeczeństwa, Wydawnictwo Difin, Warszawa 2012.

Klimek M., Działania pomocowe jednostek samorzadu terytorialnego wobec epidemii, In: N. G. Pikuła, M. Grewiński, E. Zdebska, W. Glac (eds.), Wyzwania dla polityki społecznej w kontekście pandemii koronawirusa, Biblioteka Instytutu Spraw Społecznych Uniwersytetu Pedagogicznego im. Komisji Edukacji Narodowej w Krakowie 2020, p. 37-51.

Maslow A., Motywacja i osobowość, PWN, Warszawa 2009, p. 62-76.

Morrow-Howell N., Galucia N., Swinford E., Recovering from the COVID-19 pandemic: A focus on older adults, Journal of Aging and Social Policy, 32(4-5)/2020, p. 526-535.

Nosek K., Starość zapomniana, czyli o specyfice funkcjonowaniu osób starszych $w$ nowoczesnym społeczeństwie, Kwartalnik Naukowy Fides et ratio 2(26)/2016, p. $160-168$.

Parker J.D.A., Endler N.S., Coping with coping assessment: A critical review, European Journal of Personality 6(5)/1992, p. 321-344.

Peterson O.K., Thankom A., Spillover of COVID-19: Impact on the global economy (available 27th of March 2020), https://ssrn.com/abstract $=3562570$

Petretto D.R., Pili R., Ageing and COVID19: What is the role for elderly people? Geriatrics 5(25)/2020, p. 1-4.

Prawa człowieka osób starszych podczas pandemii. wspólne stanowisko Niemieckiego Instytutu Praw Człowieka oraz Rzecznika Praw Obywatelskich Rzeczypospolitej Polskiej, Warszawa 2020 (available 23rd of April 2020), https://www.rpo.gov.pl/ sites/default/files/Wsp $\% \mathrm{C} 3 \% \mathrm{~B} 31$ ne $\% 200 \% \mathrm{C} 5 \% 9 \mathrm{Bwiadczenie} \% 20 \mathrm{RPO} \% 20 \mathrm{i} \%$ 20 DIf MR $\% 20$ w $\% 20$ sprawie $\% 20$ praw $\% 20$ os $\%$ C3 $\%$ B 3 b $\% 20$ starszych $\% 20$ podczas $\% 20$ pandemii.pdf

Przybył A., Jasiówka M., Gorczyca W., Łukasik M., Tomza P., Raport o samotności - epidemia, która jest naszą wspólną sprawą, Stowarzyszenie Wiosna, Warszawa 2020 (available 10th of April 2020), https://www.szlachetnapaczka.pl/ raport-o-samotnosci/

Riedel M., Kraus M., Informal care provision in Europe: Regulation and profile of providers, ENEPRI Research Report 96, 2011.

Samorzady lokalne: pomagamy, ale sami też potrzebujemy wsparcia (available 6th of May 2020), https://wspolnota.org.pl/news/samorzady-lokalne-pomagamyale-sami-tez-potrzebujemy-wsparcia

Szweda-Lewandowska Z., Modele opieki nad osobami niesamodzielnymi, Zeszyty Naukowe Wydziałowe Uniwersytetu Ekonomicznego w Katowicach 197/2014, p. 215-224.

The Act of September 6, 2001 on access to public information (Dz. U.2014, 782, 1662; Dz.U.2015, 1240).

Tibbitis C. (ed.), Handbook of social gerontology. Societal Aspects of Aging, Chicago University Press, Chicago, IL 1967.

Trafiałek E., Polska starość w dobie przemian, Wydawnictwo Śląsk, Katowice 2003. United Nations, The Impact of COVID-19 on older persons, Policy Brief 2020.

Who cares? Securing support in old age, Policy Brief 21/2019 (available 27th of May 2019), https://population-europe.eu/policy-briefs

Zhang Q., Song W., The challenges of the COVID-19 pandemic: Approaches for the elderly and those with Alzheimer's disease, MedComm 1(1)/2020, p. 1-5. 